\title{
Formation of properties of meat-containing canned food with the use of rabbit meat for children's and dietary food
}

\author{
Anna Merkulova*, Inessa Zachesova, and Maria Gorbacheva \\ Moscow State Academy of Veterinary Medicine and Biotechnology - MVA named after K.I. \\ Skryabin, 109472, Moscow, str. Akademika Skryabina, 23, Russia
}

\begin{abstract}
The modern level of knowledge about food products allows them to be developed with specified properties that correspond to a specific purpose. The creation of such products is always a search for a reasonable compromise between the numerous requirements for food products. The article reflects the results of a scientific study devoted to the development of a recipe for canned meat for baby food with a different percentage of rabbit meat and vegetables. Comprehensive studies of the consumer properties of canned food obtained according to one of the author's recipes were carried out.

The obtained data and their analysis made it possible to choose the most optimal option for canned food, which will be in demand and competitive in relation to other types of products in the assortment group.
\end{abstract}

\section{Introduction}

In recent years, in Russia, special attention has been paid to the production of canned food for baby food, which in terms of nutritional value, composition, degree of grinding and safety indicators correspond to the needs of the organism of a certain age group [5]. The most demanded group of products for baby food is canned meat, which has a high nutritional value due to the combination of proteins and fats of animal and vegetable origin. Rabbit meat is of significant value for this group of canned food due to its relatively low calorie content, high taste and aroma indicators and digestibility [6].The main types of raw materials for the production of meat products for the nutrition of young children are the meat of young cattle and pigs. The possibility of using other types of meat that are not inferior in safety and nutritional value, such as horse meat and rabbit meat, has also been studied. The studies were carried out at the Institute of Nutrition and positive results were obtained [8].

When developing products for baby food, such criteria as the content of protein in the finished product, its ratio with fat, the presence of vitamins and minerals necessary for the child's body must be taken into account. Table 1 shows data on the nutritional value, vitamin and mineral composition of rabbit meat in comparison with other types of meat raw materials used to obtain baby food $[8,10]$.

\footnotetext{
* Corresponding author: anutochka559@yandex.ru
} 
Table 1. Nutritional value, vitamin and mineral composition of rabbit meat [8]

\begin{tabular}{|l|c|c|c|c|}
\hline Index & Rabbit meat & Beef & Lean Pork & Lamb \\
\hline Content,\% & & & & \\
Squirrel & 22,4 & 18,7 & 16,4 & 18,5 \\
Fat & 9,65 & 12,4 & 27,8 & 15,3 \\
\hline Macronutrient content, mg / 100 g & & & & \\
& & & & \\
Potassium & 335 & 355 & 316 & 270 \\
Sodium & 57 & 73 & 64,8 & 80 \\
Calcium & 20 & 10,2 & 8 & 11 \\
Magnesium & 25 & 22 & 27 & 20 \\
Phosphorus & 190 & 188 & 170 & 190 \\
\hline Trace element content, mg / 100 g & & & & \\
& & & & \\
Gland & 3300 & 2900 & 1940 & 2090 \\
Yoda & 5 & 7 & 8 & 2,7 \\
Manganese & 12 & 35 & 28 & 35 \\
\hline The amount of vitamins, mg / 100g & & & & \\
E & & & & \\
PP & 0,5 & 0,57 & 0,54 & 0,5 \\
B ${ }_{1}$ & 6,2 & 4,7 & 2,8 & 4,1 \\
B 6 & 0,09 & 0,06 & 0,6 & 0,09 \\
B ${ }_{2}$ & 0,48 & 0,38 & 0,3 & - \\
B ${ }_{12}$ & 0,04 & 0,15 & 0,16 & 0,16 \\
B 5 & 0,004 & - & - & - \\
\hline
\end{tabular}

The dietary properties of rabbit meat are due to the fact that, in comparison with other types of meat, it has a high mass fraction of protein, with a relatively low mass fraction of fat, contains more vitamins $\mathrm{B}_{6}, \mathrm{~B}_{12}$ and $\mathrm{PP}$, rabbit meat contains less sodium. In addition, it contains many minerals necessary for the normal development of a child. The biological usefulness of rabbit meat determines a higher assimilation of its nutrients by the body in comparison with meat of other animal species [3].

Meat-containing canned food for baby food is produced according to the latest technologies in a high culture of production, without dyes and preservatives, which makes it possible to obtain a safe product with good organoleptic properties [9]. The main advantages of their industrial production in comparison with home-cooked dishes: high level of safety and quality; a previously known chemical composition; the optimal degree of grinding, corresponding to the age characteristics of the chewing apparatus and the food system of children of different ages; the convenience of use; reduction of time for cooking $[3,7]$.

When developing recipes for the enrichment of canned meat, such plant components as cauliflower, broccoli, carrots and dill were used. Due to the unique composition, low calorie content and easy digestion of cauliflower, this product should be present in the child's diet. The useful elements of cauliflower include a fairly high content of vitamin $\mathrm{K}$, fiber, $\mathrm{Ca}, \mathrm{Mg}$, ascorbic acid, which is involved in many metabolic processes and strengthens the immune system. There are many useful substances in broccoli cabbage, it is not for nothing that it is considered one of the ten most useful foods. Eating a $50 \mathrm{~g}$ serving of broccoli will provide the child's body with the daily need for nutrients. Vitamins A, C, K, U, B9, B5. Broccoli also contains phytoncides that can protect a child from viral infections or speed up recovery. No less important is the content of trace elements in cabbage: Ca, 
Mg, F, Fe, Cr, Zn, Na, Se, Cu. The value of carrots and dill lies in the content of betacarotene, provitamin A, all vitamins of group B, vitamin C, vitamin PP [4].

The purpose of this study is to develop recipes for meat-containing canned food for baby and dietetic food using rabbit meat.

\section{Research objectives}

- to substantiate and develop recipes for meat-containing canned food for baby food using rabbit meat;

- to develop a technology for obtaining canned meat for baby food using rabbit meat;

- to study the consumer properties of the obtained meat-containing canned food for baby food using rabbit meat

\section{Objects and Methods}

The objects for research were experimental versions of recipes for canned food from rabbit pulp and ingredients of plant origin: broccoli, cauliflower, carrots, dill (Table 2)

Table 2. Composition of components in the recipe of experimental options for meat-containing canned food, wt $\%$

\begin{tabular}{|c|c|c|c|}
\hline Ingredient name & \multicolumn{3}{|c|}{ The percentage of ingredients in the recipe (\%) } \\
\hline & Option 1 & Option 2 & Option 3 \\
\hline Rabbit pulp & 30 & 34,5 & 39 \\
\hline Broccoli & 26 & 24,5 & 23 \\
\hline Cauliflower & 11 & 9,5 & 8 \\
\hline Carrot & 20 & 18,5 & 17 \\
\hline Dill & 1,5 & 1,5 & 1,5 \\
\hline Salt & 1,5 & 1,5 & 1,5 \\
\hline Meat and bone broth & 10 & 10 & 10 \\
\hline
\end{tabular}

The selection of samples of canned meat and their preparation for testing was carried out in accordance with STST 8756.0-70. The assessment of organoleptic indicators was carried out in accordance with STST 8756.1-2017 “Canned food products. Methods for determining organoleptic characteristics, net weight or volume and mass fraction of constituent parts ", STST 9959-2015" Meat and meat products. General conditions for carrying out sensory evaluation ".

Study of physical and chemical indicators in accordance with STST 25011-2017 "Meat and meat products. Protein determination methods ", STST 23042-2015" Meat and meat products. Methods for the determination of fat ". The determination of the mass fraction of fat, moisture and the mass fraction of chlorides was carried out in accordance with STST R 33319-2015 and STST 51480-99, respectively. The following safety indicators were selected for research: determination of the number of mesophilic aerobic, facultatively anaerobic microorganisms, as well as determination of the amount of molds and yeasts, performed in accordance with STST 10444.15-94 and STST 28805-90, respectively.

\section{Results and its discussion}

Canned food occupies a significant share among products for children. Their technology is distinguished by high requirements for the quality of raw materials, softer heat treatment modes, elimination of its direct contact (at different stages of its processing) 
with air oxygen, as well as the possibility of balancing the chemical composition of the finished product by introducing natural biologically active products into the formulation.

When developing the production technology, modern principles of the complex use of raw materials were implemented in the design of multicomponent food systems for targeted purposes.

The technological scheme for obtaining meat-containing canned food for baby food using rabbit meat is shown in Figure 1.

Chilled raw meat was used for the production of canned food. The chilled rabbit carcasses were sent for cutting, where they were deboned and trimmed. In parallel, the preparation of auxiliary raw materials and spices was carried out. Then there was a grinding of meat and auxiliary raw materials. In the production of this type of canned food, pieces of meat weighing 100-150 g are boiled until half cooked, cut into 6-8 mm cubes. Peeled vegetables were chopped into pieces of $4-5 \mathrm{~mm}$ in size and blanched at $\mathrm{t}=98^{\circ} \mathrm{C}$. The meat and vegetables were mixed and chopped greens were added. The cans were sterilized at $\mathrm{t}=$ $115-120^{\circ} \mathrm{C}$. The mixed ingredients were placed in the jar. During sterilization, the jars were covered with boiled lids. The lids were not closed tightly so that air and vapors could freely escape from the cans. Canned food was sterilized at $\mathrm{t}=115-120^{\circ} \mathrm{C}$. Then, the cans were sealed, the canned food was cooled at $\mathrm{t}=40^{\circ} \mathrm{C}$. Storage of meat-containing canned food was carried out at $\mathrm{t}=0-25^{\circ} \mathrm{C}$

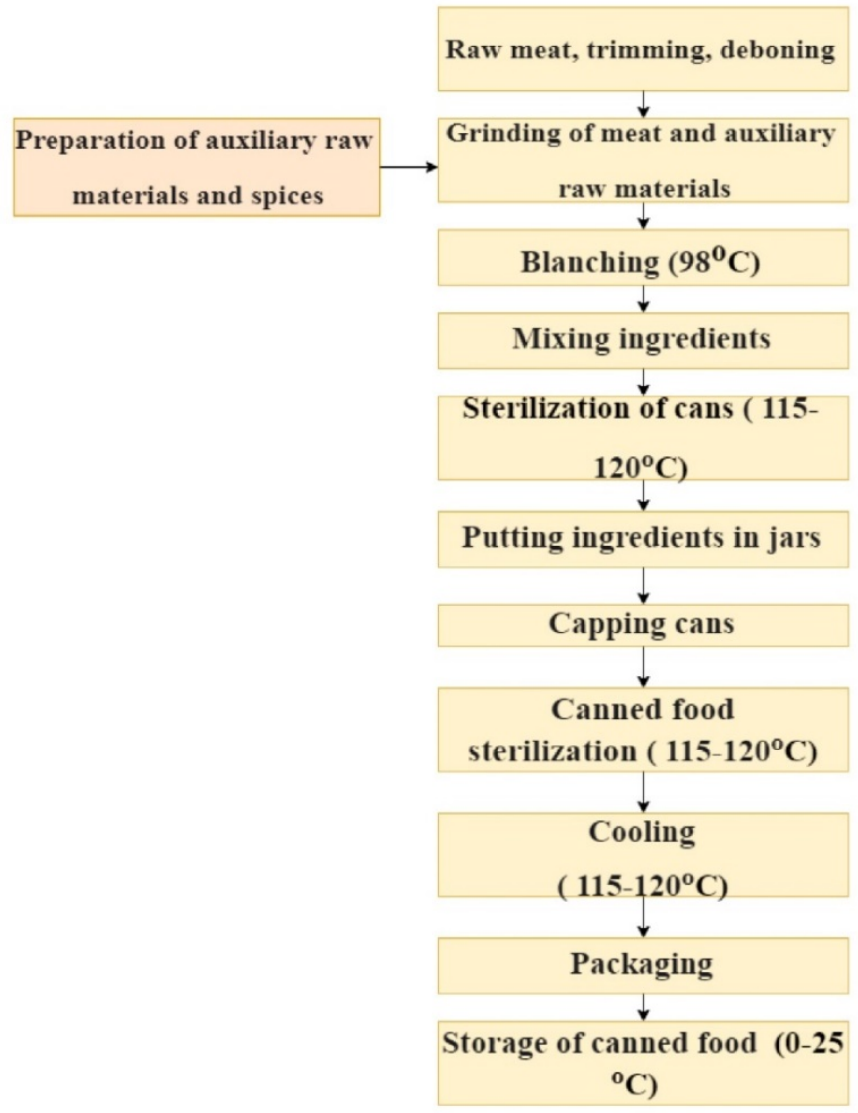

Fig. 1. Technological scheme for obtaining meat-containing canned food for baby food using rabbit meat 
The next stage was the study of the consumer properties of the obtained meatcontaining canned food for baby food using rabbit meat. Analysis of consumer properties and assessment of product quality are based on the results of determining quality indicators.

The organoleptic assessment of canned meat for baby food is presented in Table 3.

Table 3. Organoleptic indicators of the quality of canned meat for baby food [2].

\begin{tabular}{|c|c|c|c|}
\hline \multicolumn{4}{|c|}{ Characteristics and value of the indicator for canned food } \\
\hline $\begin{array}{l}\text { The name of } \\
\text { indicators }\end{array}$ & $\begin{array}{c}\text { STST 34153-2017 } \\
\text { "Canned meat containing food for } \\
\text { children over three years old" }\end{array}$ & Option 2 & Option 3 \\
\hline Appearance & $\begin{array}{l}\text { Pieces of meat or offal and vegetable } \\
\text { components weighing from } 5.0 \text { to } 20.0 \mathrm{~g} \\
\text { of arbitrary shape in their own juice, } \\
\text { sauce or broth. Pieces of meat do not } \\
\text { contain cartilage, coarse connective } \\
\text { tissue. Sauce without welded lumps of } \\
\text { flour, without signs of delamination. The } \\
\text { broth in a heated state is from yellowish } \\
\text { to light brown in color with the presence } \\
\text { of suspended protein substances in the } \\
\text { form of flakes. Slight turbidity of broth } \\
\text { is allowed }\end{array}$ & \multicolumn{2}{|c|}{$\begin{array}{l}\text { Evenly mixed mixture of pieces of } \\
\text { boneless meat and vegetables } \\
\text { weighing } 5.0-7.0 \mathrm{~g} \text {. Pieces of meat } \\
\text { do not contain cartilage, coarse } \\
\text { connective tissue. The broth is } \\
\text { yellowish when heated. }\end{array}$} \\
\hline Consi & $\begin{array}{l}\text { Pieces of meat, offal - soft, sauce - } \\
\text { homogeneous. Vegetable components } \\
\text { are soft, but not boiled, in the bulk, } \\
\text { retained their shape }\end{array}$ & $\begin{array}{l}\text { Pieces of meat } \\
\text { homogeneous. } \\
\text { components are soft, b } \\
\text { in the bulk, retained the }\end{array}$ & $\begin{array}{l}\text { Sofe soft, } \\
\text { Vegetable } \\
\text { not boiled, } \\
\text { hape }\end{array}$ \\
\hline $\begin{array}{l}\text { Smell and } \\
\text { taste }\end{array}$ & $\begin{array}{l}\text { Characteristic of the raw materials used } \\
\text { without extraneous taste and smell, } \\
\text { slightly salted taste, not spicy }\end{array}$ & $\begin{array}{l}\text { Characteristic of this } \\
\text { and vegetables, withor } \\
\text { and smell, slightly salt }\end{array}$ & $\begin{array}{l}\text { of meat } \\
\text { eign taste } \\
\text { ste }\end{array}$ \\
\hline
\end{tabular}

From the data presented in table 3, it can be noted that in terms of organoleptic parameters the samples were similar and had the following characteristics: pieces of boneless meat and vegetables are evenly mixed and do not contain cartilage, coarse connective tissue. The plant components are soft, but not boiled, retained their shape. The broth is yellowish when heated. Objects have a characteristic odor and slightly salty taste.

According to the results of the organoleptic assessment, it was found that the appearance of the objects meets the requirements of STST 34153-2017 "Meat-containing canned food for children over three years old", presented in terms of organoleptic indicators to this type of canned food.

Due to the fact that a scoring system is used to quantify quality indicators in organoleptic assessment, a tasting assessment was carried out in the work on a 9-point scale in accordance with STST 9959-2015. "Meat products. General conditions for carrying out sensory evaluation ". Each point corresponds to a certain level of quality, characterized by a verbal description (Table 4). 
Table 4. Tasting assessment of the quality of canned meat for baby food

\begin{tabular}{|c|c|c|c|}
\hline \multirow{2}{*}{ The name of indicators } & \multicolumn{4}{|c|}{$\mathrm{n}=5$} \\
\cline { 2 - 4 } & Option 1 & Option 2 & Option 3 \\
\hline Appearance & 8,3 & 8,3 & 8,3 \\
\hline Smell (scent) & 6,3 & 8,3 & 7,6 \\
\hline Taste & 7,3 & 8,0 & 7,3 \\
\hline $\begin{array}{c}\text { Consistency } \\
\text { tenderness, hardness) }\end{array}$ & 7,0 & 7,0 & 7,0 \\
\hline Juiciness & 7,6 & 7,6 & 7,6 \\
\hline Average mark & $\mathbf{7 , 3}$ & $\mathbf{7 , 9}$ & $\mathbf{7 , 6}$ \\
\hline $\begin{array}{c}\text { Overall quality } \\
\text { assessment }\end{array}$ & $\mathbf{G o o d}$ & Very good & Very good \\
\hline
\end{tabular}

From the results of table 4, according to the tasting assessment of the quality of canned food, it can be seen that objects 2 (with 34.5\% content of rabbit meat) and 3 (with $39 \%$ content of rabbit meat) have a quality rating of "Very good", object 1 (from 30, 0\% rabbit meat content) has a quality rating of "Good".

Object No. 1 has a reduced score for the specific smell of these canned food, with this percentage of ingredients. The volatile aromas in the meat enhance the flavor of the vegetables.

For objects No. 2 and No. 3, tasters noted a more pleasant and less intense aroma. Object No. 2, according to the commission, has the highest taste in comparison with others, as evidenced by a high score.

The usefulness of food products depends on their chemical composition and the characteristics of the transformation of individual nutrients in the child's body. In this regard, energy, biological, physiological, organoleptic value, as well as biological effectiveness, digestibility and safety of PDP are distinguished.

Nutritional value characterizes the full completeness of the useful properties of the product and its taste, due to the various nutrients it contains. The nutritional value is the higher, the more the product satisfies the physiological needs of the body for these substances and ensures its normal functioning [11].

The results of research on the physical and chemical parameters of canned food are shown in Table 5.

Table 5. Physicochemical indicators of the quality of options for meat-containing canned food for baby food

\begin{tabular}{|c|c|c|c|c|}
\hline \multirow{2}{*}{$\begin{array}{l}\text { Variants of prototypes of } \\
\text { canned meat }\end{array}$} & \multicolumn{4}{|c|}{ Indicators of chemical composition,\% } \\
\hline & $\begin{array}{l}\text { Mass fraction of } \\
\text { moisture }\end{array}$ & $\begin{array}{l}\text { Mass fraction } \\
\text { of fat }\end{array}$ & $\begin{array}{l}\text { Mass fraction of } \\
\text { protein }\end{array}$ & $\begin{array}{l}\text { Mass fraction } \\
\text { of salt }\end{array}$ \\
\hline 1 & 77,8 & 7,8 & 10,54 & 0,34 \\
\hline 2 & 78,4 & 7,4 & 10,98 & 0,31 \\
\hline 3 & 79,2 & 6,8 & 11,17 & 0,28 \\
\hline $\begin{array}{l}\begin{array}{l}\text { Requirements of STST } \\
34153-2017\end{array} \\
\end{array}$ & - & $\begin{array}{c}\text { No more than } \\
15\end{array}$ & $\begin{array}{c}\text { Not less than } \\
4,0\end{array}$ & - \\
\hline
\end{tabular}

According to the data obtained, with an increase in the percentage of rabbit meat in the recipe, the mass fraction of protein increases accordingly - from $10.54 \%$ in object 1 , in object No. 2 - 10.98\% to in object No. $3-11.17 \%$; indicators of the mass fraction of fat are reduced and amount to $7.8 \%$ in object $1,7.4 \%$ in object No. 2 and $6.8 \%$ in object No. 3 ; the mass fraction of salt is $0.34 \%$ in object $1,0.31 \%$ in object No. 2 and $0.28 \%$ in object No. 3 . 
Changes in physical and chemical parameters are associated with the\% ratio of ingredients in the recipe. It is noted that the results do not exceed the limits of the prescribed values and meet the requirements of STST 34153-2017 "Meat-containing canned food for children over three years old."

Microbiological studies of experimental options for meat-containing canned food for baby food for compliance with the requirements of TR CU 034/2013 "On the safety of meat and meat products" were carried out in the testing center "TEST QUALITY" LLC [1] (Table 6).

Table 6. Microbiological indicators of the quality of canned meat for baby food [1].

\begin{tabular}{|c|c|c|c|c|}
\hline \multirow[t]{2}{*}{ Indicators } & \multirow[t]{2}{*}{ Requirements } & \multicolumn{3}{|c|}{ Prototype options } \\
\hline & & 1 & 2 & 3 \\
\hline $\begin{array}{lr}\text { Inspection, } & \text { dignity. } \\
\text { processing, determination } \\
\text { of tightness }\end{array}$ & No defects & $\begin{array}{l}\text { Cans } \\
\text { without } \\
\text { defects, } \\
\text { sealed }\end{array}$ & $\begin{array}{l}\text { Cans } \\
\text { without } \\
\text { defects, } \\
\text { sealed }\end{array}$ & $\begin{array}{l}\text { Cans } \\
\text { without } \\
\text { defects, } \\
\text { sealed }\end{array}$ \\
\hline Thermostatting & 5 days at $\mathrm{T}-37^{\circ} \mathrm{C}$ & $\begin{array}{l}\text { Without } \\
\text { changes }\end{array}$ & $\begin{array}{l}\text { Without } \\
\text { changes }\end{array}$ & $\begin{array}{l}\text { Without } \\
\text { changes }\end{array}$ \\
\hline $\begin{array}{l}\text { Determination of } \\
\text { appearance after incubation }\end{array}$ & No defects & $\begin{array}{l}\text { Cans } \\
\text { without } \\
\text { defects, } \\
\text { sealed } \\
\end{array}$ & $\begin{array}{l}\text { Cans } \\
\text { without } \\
\text { defects, } \\
\text { sealed } \\
\end{array}$ & $\begin{array}{l}\text { Cans } \\
\text { without } \\
\text { defects, } \\
\text { sealed }\end{array}$ \\
\hline $\begin{array}{l}\text { Spore-forming mesophilic } \\
\text { aerobic and facultative } \\
\text { anaerobic microorganisms } \\
\text { of the B. subtillis group }\end{array}$ & $\begin{array}{l}\text { Allowed, but not more } \\
\text { than } 11 \text { cells per } 1 \mathrm{~g} \text { of } \\
\text { product }\end{array}$ & $\begin{array}{c}\text { Not } \\
\text { detected }\end{array}$ & $\begin{array}{c}\text { Not } \\
\text { detected }\end{array}$ & $\begin{array}{c}\text { Not } \\
\text { detected }\end{array}$ \\
\hline $\begin{array}{l}\text { Spore-forming mesophilic } \\
\text { aerobic and facultative } \\
\text { anaerobic microorganisms } \\
\text { of the B.cereus and } \\
\text { B.polymyxa groups }\end{array}$ & Not allowed & $\begin{array}{c}\text { Not } \\
\text { detected }\end{array}$ & $\begin{array}{c}\text { Not } \\
\text { detected }\end{array}$ & $\begin{array}{c}\text { Not } \\
\text { detected }\end{array}$ \\
\hline Mesophilic Clostridia & $\begin{array}{l}\text { Allowed except for C. } \\
\text { botulinum C. } \\
\text { perfringens, should not } \\
\text { exceed } 1 \text { cell in } 1 \mathrm{~g} \text { of } \\
\text { product }\end{array}$ & $\begin{array}{c}\text { Not } \\
\text { detected }\end{array}$ & $\begin{array}{c}\text { Not } \\
\text { detected }\end{array}$ & $\begin{array}{c}\text { Not } \\
\text { detected }\end{array}$ \\
\hline $\begin{array}{c}\text { Non-spore-forming } \\
\text { microorganisms and (or) } \\
\text { mold fungi and (or) yeast }\end{array}$ & Not allowed & $\begin{array}{c}\text { Not } \\
\text { detected }\end{array}$ & $\begin{array}{c}\text { Not } \\
\text { detected }\end{array}$ & $\begin{array}{c}\text { Not } \\
\text { detected }\end{array}$ \\
\hline
\end{tabular}

\section{Findings}

According to the results of the studies of organoleptic indicators and tasting assessment of the quality of canned meat for baby food, it was found that the product obtained according to recipe No. 2 has the best organoleptic and taste-aromatic properties, the general assessment of the quality of the product is "Very good".

It is shown that with an increase in the percentage of rabbit meat in the composition, the mass fraction of protein in the product increases.

The use in the production of canned meat for baby food as prescription ingredients of rabbit meat and vegetable raw materials (broccoli, cauliflower, carrots and dill) is a promising direction, contributes to the expansion of the range, enrichment with physiologically significant components. 


\section{References}

1. TR CU 034/2013 "On the safety of meat and meat products" (adopted by the Decision of the Council of the Eurasian Economic Commission dated October 9, 2013 No. 68). Access mode: URL: http://docs.cntd.ru/document/499050564 (date of access: 11.10.2020)

2. GOST 34153-2017 Canned meat-containing food for children over three years old. M.: Standartinform, 2017.16 p.

3. Korochkina R.S., Kuznetsov V.V. Raw materials supply and the state of domestic production of baby food // Food industry. 2012. No. 3. S. 16-20.

4. Velichko N.A., Mashanov A.I., Buyanova I.V. The possibility of using broccoli cabbage for enrichment of minced meat semi-finished products // Bulletin of KrasGAU. 2018. No. 3. S. 160-164.

5. Zachesova I.A., Kindirova S.I. Assessment of the quality of canned venison from various manufacturers // collection of proceedings of the National Scientific and Practical Conference Commodity Science, Technology and Expertise: Innovative Solutions and Development Prospects. Moscow, 2018.S. 155-160.

6. Diet canned food from meat and rabbit liver / I.M. Chernukha, L.B. Smetanina, A.N. Zakharov et al. // ALL ABOUT MEAT. 2006. No. 2. S. 14-16.

7. Danilova I.A., Borodin A.V., Barbashinskaya V.V. Organization of the technological process at a meat-processing enterprise using the HACCP system // Proceedings of the National Scientific and Practical Conference "Scientific and Practical Foundations in the Field of Commodity Science, Technology, Organization of Commercial Activity and Ecology". Moscow, 2019.S. 28-32.

8. Ustinova A.V., Derevitskaya O.K., Kretov M.A. The use of rabbit meat in the nutrition of young children // ALL ABOUT MEAT. 2006. No. 4. S. 18-19

9. Organization and conduct of practical training at slaughterhouse enterprises and in state laboratories of veterinary and sanitary examination of food markets: textbook / Borovkov M. F., Redkin S. V., Volkov A. T. and others. M .: OOO "CrossMediaKom", 2017.107 p.

10. Borovkov M.F., Petrova Yu. V., Novikova M.A. Organoleptic characteristics of rabbit meat when used in the diet of the antioxidant Emidonol // collection of proceedings of the International educational-methodical and scientific-practical conference dedicated to the 95th anniversary of the Department of Parasitology and Veterinary and Sanitary Expertise. Moscow, 2015.S. 196-199.

11. Borovkov M.F., Bachinskaya V.M., Deltsov A.A. Veterinary and sanitary assessment of the quality of rabbit meat when using the drug "Bio-iron with microelements": guidelines. M .: "ZooVetKniga", 2013.19 p. 